\title{
Contrasting Ohio Nursery Stock Availability with Community Planting Needs
}

\author{
T. Davis Sydnor, Sakthi Subburayalu, and Matthew Bumgardner
}

\begin{abstract}
There has been a continuing disparity between what urban foresters say they request for community plantings and the stock availability from nurseries. To investigate this, twenty-two of Ohio's urban foresters were surveyed in February 2008 to contrast their planting needs with nursery stock availability. Urban foresters reported planting more than 9,000 trees in 2005 and expected to plant more than 15,000 trees in their respective communities in 2010. At the same time, nearly 278,000 trees [ $5 \mathrm{~cm}(2 \mathrm{in})]$ were reported as being available for sale by nurseries participating in the 2008 Ohio Nursery Stock Survey. The results suggested that maples, crabapples, many hawthorns, and pears generally were present in nurseries in excess of the quantities desired by urban foresters. Conversely many legumes, oaks, elms, lilacs and lindens were lacking in availability. Several other species were somewhat balanced in terms of urban foresters' requests and nursery production. Ohio, U.S. has been dealing with the impacts of the emerald ash borer on Fraxinus species. Increasing taxonomic diversity can be a relatively low cost means of insuring against the possible introduction of another exotic pest that might attack another genus (such as Acer) and requires increased availability of some species currently lacking in availability in the nursery supply chain.

Key Words. Acer; Community Planting; Crataegus; Fraxinus; Gleditsial; Malus; Nursery Stock Availability; Pyrus; Quercus; Tilia; Ulmus.
\end{abstract}

A commonly reported paradox has been heard when talking with urban foresters and nursery producers in the state of Ohio, U.S. Urban foresters claim they cannot get the plants they desire for planting on community streets, in parks, or in other public spaces, and must settle for second or third choices. Nursery producers, in contrast, claim that they will produce anything customers wish if they become aware of a demand. In order to bridge the gap between trees desired by urban foresters and those available from producing nurseries in the state, surveys of urban foresters were taken in 1995,2000 , and 2008. Summary results were published in the Buckeye (the official publication of the Ohio Nursery and Landscape Association), so that results would be available to the Ohio nursery community (Sydnor 1996; Sydnor et al. 2000; Sydnor 2008).

Some nurseries have responded and are growing some previously requested plants but many urban foresters find they are still unable to get their first choice in plant material. Another part of the puzzle would be to compare what is being requested with what is actually available for sale in nurseries. Nurseries have had information on what was requested in the 1995, 2000, and 2008 surveys, but neither the urban foresters nor nurseries have had a feel for the supply side of the equation. This study seeks to address this problem.

The impact of emerald ash borer (EAB) has reinforced the need for increased diversity in urban forests. Communities often try to limit a single species to $10 \%$, a genus to $20 \%$, and families to $30 \%$ (10-20-30 rule or guideline) of the trees in their forest (Santamour 1990). Using these criteria, many Ohio communities are too heavily planted in maple and pear. For example, some Ohio community public spaces have been found to contain more than 30\% maple (Sydnor and Subburayalu 2008a; Sydnor and Subburayalu 2008b). Ohio's original shade tree evaluation project, which included 97 community plantings, found 27 of the plantings (28\%) were maple (Sydnor et al. 1999).
A 2007 survey of urban foresters suggested a potential economic impact of EAB in Ohio communities at USD \$2 to \$8 billion (Sydnor et al. 2007). Furthermore, about $8 \%$ of community forests in Ohio are in ash species, while maples are in excess of $30 \%$ (Sydnor and Subburayalu 2008a). Given that maple abundance is approximately four times greater than ash abundance, the statewide community impact might reach $\$ 8$ to $\$ 30$ billion if a similarly devastating exotic pest of maple were to strike. Biological diversity is a relatively inexpensive way to deal with the threat of exotic pests, especially when compared to removing and replacing trees. While these examples relate specifically to Ohio and the Midwest, other regions in the United States and even other countries have imbalances they must consider as well (McBride 2008). The southeastern U.S., for example, depends too heavily on oak species while other regions have different imbalances.

Previous surveys of nursery stock needs have concentrated on urban foresters with the results published in literature available to the nursery producer. However, if urban foresters had some notion of what might be available, they could seek additional suppliers, encourage existing suppliers to produce material that might not be available, grow some material themselves, or develop contracts for plants to be produced in the future. Columbus, Ohio, expanded its own nursery in the 1990s to produce plants for out planting as a result of the inability to gain the desired mix of plants (Low 2008). Existing nursery stock surveys are designed for an individual to identify a grower from whom a given plant might be secured; they convey information to outlets marketing to the final user but are not designed to provide information to upstream segments in the supply chain-such as liner or seedling producers-who are likely to be in other states. To this end, a survey of existing nursery stock relative to current and anticipated needs by urban foresters for community 
plantings would be useful. The objective of this study was to identify differences between what was requested by urban foresters and what nurseries offer for sale and to provide a means for a community forester to begin a dialog with potential suppliers to provide less commonly grown trees for use on community streets.

\section{MATERIALS AND METHODS}

In February 2008, fifty-nine e-mail surveys were sent to all of Ohio's urban foresters on the Ohio Division of Forestry's community urban forester mailing list. The survey instrument was similar to those used in previous years (Sydnor 1996; Sydnor et al. 2000; Sydnor 2008). Responses could be returned by e-mail, FAX, or postage mail. A follow-up survey mailing was not conducted. A total of twenty-two responses were returned for a $39 \%$ response rate. Responses were received from all areas of the state and all community size classes.

Urban foresters were asked to identify, from a predetermined list on the survey form, how many trees of a species were planted in 2005 and how many plants of the same species were expected to be planted in 2010. The original list contained more than 200 species of trees that might be planted on Ohio streets. Of the plants listed on the survey form, responses were given for 183 taxa. Plants requested one or more times for either 2005 or 2010 were identified for comparison with the nursery stock survey. Plants not requested by urban foresters but grown by Ohio nursery producers were not evaluated. Respondents were asked for contact information in case follow-up questions were needed. Appendix 1 shows an abbreviated survey instrument with the first five lines presented.

In March 2008, permission was obtained to access the online version of the Ohio Nursery Stock Survey (Anonymous 2008). Table 1 gives an example of a portion of a stock survey entry. Nursery stock entries are reported by taxa, grower, plant size, production method (container or field), and quantity. Individual records were created for each nursery, $5 \mathrm{~cm}$ (2 in) size, production method, and taxa, with an associated quantity code. Quantity codes in the nursery stock survey represented ranges, such as 50-100 plants. The range mid-point, 75 in this example, was entered into the resulting database for further exploration. Family, genera and species codes were assigned by the investigators. All cultivars, size, production technique, and quantity counts were combined into a single species count. Information on grower was not carried into the evaluation. Counts thus represented the totals of all growers with $5 \mathrm{~cm}$ trees of a single genus and species (including all cultivars). There were a total of 277,856 trees listed for sale from the Ohio Nursery Stock Survey for 2008 in the 5 $\mathrm{cm}$ size class (as described in the next section, this was the plant size most commonly purchased by responding urban foresters).

There were 9,279 trees planted in 2005 in the respondents' 22 communities, and 15,333 requests for trees anticipated for planted during 2010. It was decided to normalize the data such that comparisons could be made between years and sources. Thus, in 2005 , responding urban foresters planted 9,279 of the 277,856 trees available in Ohio nurseries (3.339\% of the trees available). By multiplying the number of trees of a given species available in nurseries by 0.03339 (3.339\%), one obtains the number of trees available to communities for planting. Then by subtracting the number planted in 2005 from the number available in nurseries, one gets a measure of the difference between available trees relative to planting needs. A positive number for a given family or species suggests an excess of trees in nurseries, while negative numbers indicate a shortage of plants available for communities from nurseries. Similarly, in 2010, there were 15,333 requests anticipated by responding urban foresters. The 277,856 trees listed for sale in the 2008 Ohio Nursery Stock Survey were again used as the nursery stock base. If one divides the 15,333 forester requests by 277,856 (trees available), one finds that $5.518 \%$ of Ohio nursery output will be requested by these communities for 2010 .

Table 1. An example of an Ohio Nursery Stock Survey entry for a given species. Grower codes are listed in the first column, and sizes in the remaining columns. Quantity codes for each grower are noted under the size headings with numeric codes given for container plants and alpha codes for B\&B stock.

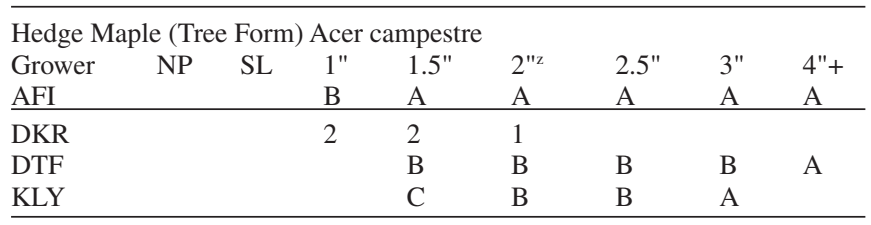

${ }^{\mathrm{z}}$ Column contains the data used to generate nursery availability.

\section{RESULTS AND DISCUSSION}

The survey of urban foresters showed that trees were normally purchased as $5 \mathrm{~cm}$ plants. Thus it was this size of plant for which quantities were recorded from the Nursery Stock Survey. Results contrasting nursery stock availability with urban foresters' planting requests for 2005 and 2010 are reported at the family and species levels. After a review of the data, a cut-off of plus or minus 70 trees was selected for brevity of presentation in the species table (Table 2). As shown in Appendix 2, several species were somewhat balanced in terms of urban foresters' requests and nursery production.

\section{Family Level}

The rose family had the greatest excess with 628 more plants available to communities than were requested in 2005 and with nearly 2,282 more available for 2010 (Table 3 ). Plants in the rose family are generally smaller flowering trees, such as crabapples and medium-sized Callery pears. Crabapples are often planted beneath utility lines and both crabapples and Callery pears are frequently planted in sidewalk cuts or smaller tree lawns. This will likely continue as crabapples and pears are among the only flowering trees capable of withstanding the environmental stress found in these planting sites. This also likely reflects the heavy demand for flowering trees in landscape applications.

Whereas species from the rose family are smaller trees with reduced environmental benefits, maples are generally used as canopy trees. Most of the environmental benefits of trees in urban areas accrue to larger trees (Sydnor and Subburayalu 2008a); as a result, communities are often planting larger trees where the site allows. Toward this end, maple availability in Ohio nurseries exceeded what urban foresters wanted both in 2005 and 2010, by 536 and 1,178 plants, respectively. Maples have become popular street trees for a variety of reasons, including ease of clonal propagation, ease of transplant, shade, often vivid fall color, and marketing efforts by nursery suppliers. Further analysis in many cities, however, suggest canopy-sized maples are currently present 
in excess of the 10-20-30 rule (Santamour 1990). For example, maples constituted $50 \%$ of the street trees in Toledo, Ohio, and $37 \%$ of the trees representing $56 \%$ of the canopy cover in Xenia, Ohio (Sydnor and Subburayalu 2008a; Sydnor and Subburayalu 2008b). Based on the 10-20-30 guidelines, it would not be recommended to plant maples in Ohio's public spaces unless or until community stocking levels are reduced below $20 \%$ to reduce the potential risk of an introduced exotic pest such as the Asian longhorned beetle that might attack maples (Fater 2008). In another study, when demand was expressed as percent market share, the demand for maples by urban foresters was expected to decline by almost two percentage-points from 2005 to 2010 (Sydnor 2008).

The Cornaceae, Hamamelidaceae, and Pinaceae families tended to be available in excess of quantities demanded by urban foresters. Pines and spruce are rarely used as street trees in Ohio, but commonly available due to demand for landscape plantings. Likewise, many plants in the dogwood family are forest understory plants and infrequently used on community streets.

Plants in the Betulaceae, Eucommiaceae, Fagaceae, Leguminosaea, Oleaceae, Platanaceae, Tiliaceae, and Ulmaceae families generally are lacking in availability. Seed sources are important for plants in the beech family, thus making propagation more difficult. For example, pin oak, a member of Fagaceae, is native and adaptable if grown from local seed sources in the higher $\mathrm{pH}$ of central Ohioan soils, but is prone to develop an iron deficiency if grown from seed plants adapted to an acidic soil region of the United States.

\section{Genus and Species Level}

When considering species, Acer palmatum (Japanese), A. platanoides (Norway), A. saccharum (sugar), A. $\times$ Freemanii (Freeman), and A. rubrum (red) maples demonstrated excess availability for both 2005 and 2010 (Table 2). Conversely, Acer campestre and $A$. truncatum maples were deficient in availability for 2005 and 2010, while A. buergeranum and A. ginnala maples supplies appeared to fall short of anticipated demand for 2010.

The projected lack of downy serviceberry may simply be a nomenclatural problem as Amelanchiers are often sold under more than one scientific name. Most cultivars seen in the nursery trade are Amelanchier $\times$ grandiflora but are sold under a variety of names.

Carpinus betulus (European hornbeam) was projected to be in limited supply for both 2005 and 2010. Interestingly, this plant has not done well in Ohio except in the colder areas (Sydnor et al. 1999). The senior author has observed this plan doing well north of Ohio. Hornbeam borer attacks plants in the warmer areas of Ohio.

Crataegus (hawthorns) establish but perform poorly in stressful urban sites, such as tree lawns, in Ohio (Sydnor et al. 1999), and now tend to be used in less stressful lawn panels or plant beds. Hawthorn hybrids were or are projected to be lacking in availability. Crataegus viridis, C. punctata, C. Phaenopyrum, and C. crus-galli inermis hawthorns are also utilized in landscape plantings with green and thornless cockspur hawthorn being available in excess of demand.

Ash (Fraxinus spp.) was an interesting situation with a warning as to the importance of taxonomic diversity. In February 2003, EAB was discovered in Lucas County, Ohio. In spring 2004, the landscape market for ash collapsed. Ohio communities planted few ash trees to fill in plantings or for special requests in 2005, and none were requested for 2010. The plant was not listed in the 2008 Ohio Nursery Stock Survey.
Gleditsia triacanthos inermis (thornless honeylocust) was deficient in availability for 2005 but in excess for 2010. Communities have been reducing the use of honeylocust as a street tree as it frequently damages sidewalks but performs well and rarely exceeds $10 \%$ of an Ohio community's urban forest. If properly sited, this tree could be used more frequently. Some communities substitute Gymnocladus dioicus (Kentucky coffeetree), for honeylocust. This leguminous tree grows slowly in nursery production and has an open, irregular canopy making it unpopular with many growers thus explaining its limited availability in 2010.

Parrotia persica (Persian parrotia) and Phellodendron amurense (Amur corktree) are projected as deficient in availability for 2010 despite urban forester's lack of experience with this tree. Communities looking for greater diversity are seeking these plants. This may represent a possible marketing opportunity for producers.

Platanus spp. were deficient in availability in 2005 and are projected to be so in 2010 as well. Communities favor London planetree $(P . \times$ acerifolia $)$ for planting despite its being marginally cold hardy because of resistance to sycamore anthracnose, a common cosmetic disease. Sycamore (P. occidentalis), in contrast, has been variably sensitive to the cosmetic disease but resistant to cankerstain (often fatal to London planetrees in Ohio). Interestingly, if demand were expressed as an expected change in percent market share from 2005 to 2010, sycamore would be increasing slightly while London planetree would be diminishing (Sydnor 2008).

Prunus sp. (cherries and plums) were variable with some shortages in flowering cherries as communities seek alternatives to crabapples and pears. When considered as percent market share, cherries are generally decreasing in community demand (Sydnor 2008). Plums and cherries are more commonly seen in private landscapes rather than streetscapes.

Quercus spp. (oaks) are variable but generally lacking in availability, especially for 2010. Many nursery professionals prefer to grow clones and many oaks are difficult to propagate asexually. Additionally, many oaks take additional time to grow which adds to a nursery's costs. Despite these challenges, oaks appear to be a real opportunity for nursery producers given the increasing interest from urban foresters.

Pekin (Syringa pekinensis) and Japanese (S. amurensis) tree lilacs are deficient in availability and increasing in demand as a percent market share (Sydnor 2008). They are being used as flowering trees but are small in stature and slow growing in tree lawns.

Lindens (Tilia sp.) are generally undersupplied with American ( $T$. americana) and silver ( $T$. tomentosa) being in highest demand. Again inaccurate nomenclature in this genus may factor in the results shown.

Elms (Ulmus sp.) are generally lacking in availability. Fast growth and urban tolerance are among the assets for elm species. Disease resistance has been identified for many serious problems, but some cosmetic concerns are present. Interestingly, lacebark elm (U. parvifolia) was one of the few elms decreasing in demand when expressed as change in percent market share (Sydnor 2008). Overall, availability fell short in this study for 2005 and 2010. Elm seems poised to be among the most popular species for landscape applications in another ten years. 
Table 2. Total nursery availability (number of trees by species), number of trees available to responding communities, number of trees planted by responding communities, and difference between availability and plantings, 2005 and 2010 . Trees with availability within +/- 70 trees are not shown in this table but are listed by scientific name in Appendix 2.

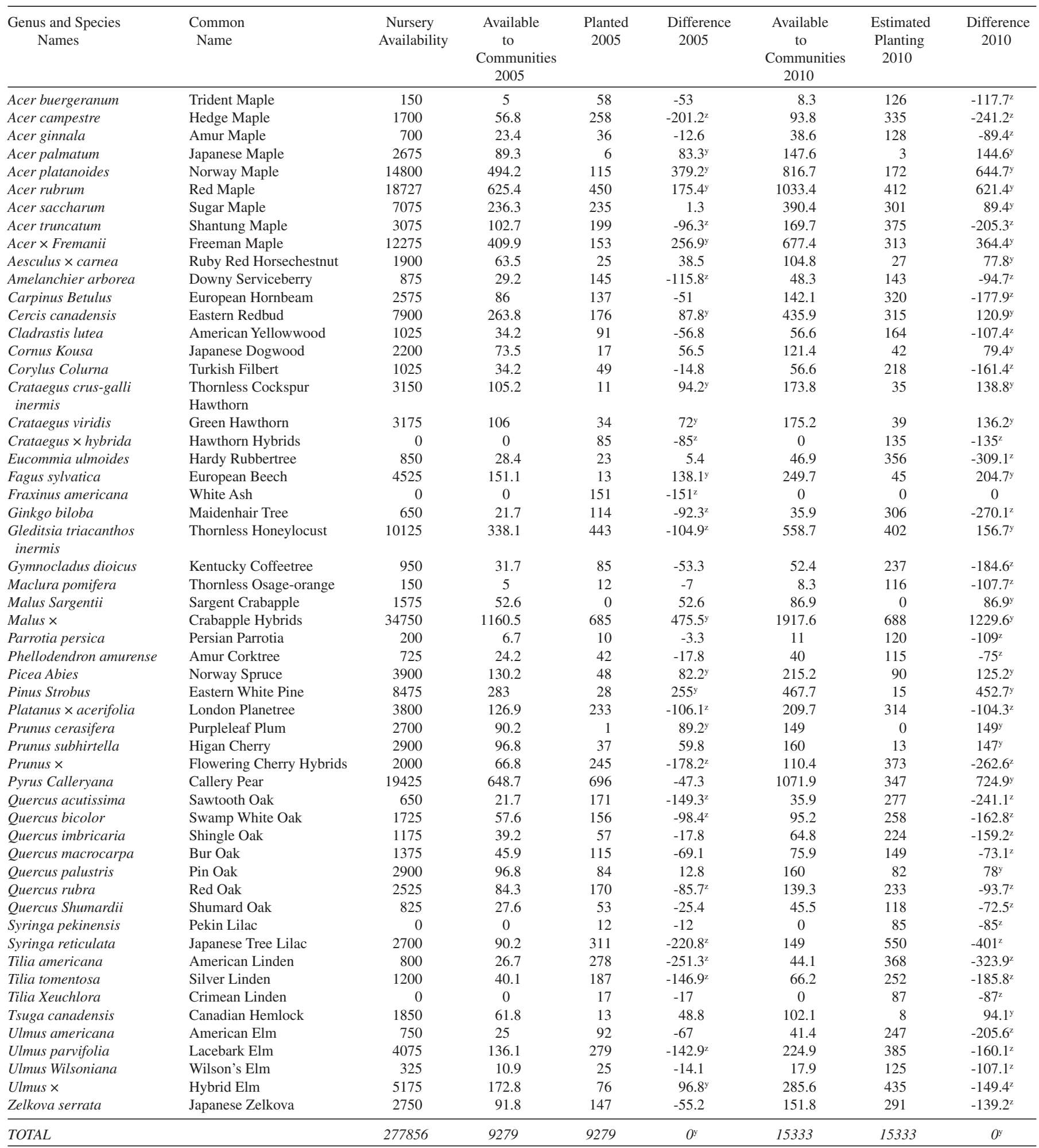

${ }^{2}$ Represent deficient availability (for differences of $+/-70$ trees or more).

${ }^{y}$ Represents excess availability (for differences of $+/-70$ trees or more). 
Table 3. Total nursery availability (number of trees by family), number of trees available to responding communities, number of trees planted by responding communities, and difference between availability and plantings, 2005 and 2010.

\begin{tabular}{|c|c|c|c|c|c|c|c|c|}
\hline Family Name & Common Name & $\begin{array}{c}\text { Nursery } \\
\text { Availability }\end{array}$ & $\begin{array}{l}\text { Available } \\
\text { to } \\
\text { Communities } \\
2005\end{array}$ & $\begin{array}{c}\text { Planted } \\
2005\end{array}$ & $\begin{array}{l}\text { Difference } \\
2005\end{array}$ & $\begin{array}{c}\text { Available } \\
\text { to } \\
\text { Communities } \\
2010\end{array}$ & $\begin{array}{c}\text { Estimated } \\
\text { Planting } \\
2010\end{array}$ & $\begin{array}{c}\text { Difference } \\
2010\end{array}$ \\
\hline Anacardiaceae & Cashew & 1504 & 50.2 & 6 & 44.2 & 83.0 & 22 & 61.0 \\
\hline Annonaceae & Annona & 225 & 7.5 & 15 & -7.5 & 12.4 & 35 & -22.6 \\
\hline Aquifoliaceae & Holly & 125 & 4.2 & 7 & -2.8 & 6.9 & 13 & -6.1 \\
\hline Betulaceae & Birch & 8375 & 279.7 & 353 & $-73.3^{y}$ & 462.2 & 947 & $-484.8^{y}$ \\
\hline Caprifoliaceae & Honeysuckle & 475 & 15.9 & 16 & -0.1 & 26.2 & 18 & 8.2 \\
\hline Cercidiphyllaceae & Katsura & 675 & 22.5 & 64 & -41.5 & 37.2 & 50 & -12.8 \\
\hline Cornaceae & Dogwood & 4325 & 144.4 & 71 & $73.4^{\mathrm{z}}$ & 238.7 & 164 & $74.7^{z}$ \\
\hline Cupressaceae & Cypress & 775 & 25.9 & 0 & 25.9 & 42.8 & 20 & 22.8 \\
\hline Ebenaceae & Ebony & 100 & 3.3 & 20 & -16.7 & 5.5 & 31 & -25.5 \\
\hline Ericaceae & Heath & 975 & 32.6 & 0 & 32.6 & 53.8 & 11 & 42.8 \\
\hline Eucommiaceae & Eucommia & 850 & 28.4 & 23 & 5.4 & 46.9 & 356 & $-309.1^{y}$ \\
\hline Fagaceae & Beech & 20400 & 681.3 & 990 & $-308.7^{y}$ & 1125.7 & 1895 & $-769.3^{y}$ \\
\hline Hippocastanaceae & Horsechestnut & 5500 & 183.7 & 47 & $136.7^{z}$ & 303.5 & 147 & $156.5^{z}$ \\
\hline Juglandaceae & Walnut & 275 & 9.2 & 7 & 2.2 & 15.2 & 44 & -28.8 \\
\hline Lauraceae & Laurel & 75 & 2.5 & 12 & -9.5 & 4.1 & 15 & -10.9 \\
\hline Leguminosae & Legume & 20700 & 691.3 & 888 & $-196.7^{y}$ & 1142.3 & 1232 & $-89.7^{y}$ \\
\hline Magnoliaceae & Magnolia & 5725 & 191.2 & 162 & 29.2 & 315.9 & 350 & -34.1 \\
\hline Malvaceae & Mallow & 0 & 0.0 & 0 & 0.0 & 0.0 & 7 & -7.0 \\
\hline Moraceae & Mulberry & 825 & 27.6 & 12 & 15.6 & 45.5 & 117 & $-71.5^{y}$ \\
\hline Nyssaceae & Blackgum & 1025 & 34.2 & 38 & -3.8 & 56.6 & 93 & -36.4 \\
\hline Oleaceae & Olive & 3550 & 118.6 & 550 & $-431.4^{y}$ & 195.9 & 668 & $-472.1^{y}$ \\
\hline Pinaceae & Pine & 18875 & 630.3 & 231 & $399.3^{z}$ & 1041.6 & 334 & $707.6^{z}$ \\
\hline Platanaceae & Planetree & 5000 & 167.0 & 294 & $-127.0^{y}$ & 275.9 & 430 & $-154.1^{y}$ \\
\hline Rosaceae & Rose & 82850 & 2766.8 & 2138 & $628.8^{z}$ & 4571.9 & 2290 & $2281.9^{z}$ \\
\hline Rutaceae & Rue & 725 & 24.2 & 42 & -17.8 & 40.0 & 120 & $-80.0^{y}$ \\
\hline Salicaceae & Willow & 675 & 22.5 & 1 & 21.5 & 37.2 & 71 & -33.8 \\
\hline Sapindaceae & Soapberrry & 525 & 17.5 & 22 & -4.5 & 29.0 & 75 & -46.0 \\
\hline Scrophulariaceae & Figwort & 0 & 0.0 & 0 & 0.0 & 0.0 & 0 & 0.0 \\
\hline Simaroubaceae & Quassia & 0 & 0.0 & 0 & 0.0 & 0.0 & 1 & -1.0 \\
\hline Tiliaceae & Linden & 5550 & 185.3 & 649 & $-463.7^{y}$ & 306.3 & 900 & $-593.7^{y}$ \\
\hline Ulmaceae & Elm & 14375 & 480.1 & 715 & $-234.9^{y}$ & 793.3 & 1678 & $-884.7^{y}$ \\
\hline TOTAL & & 277856 & 9279.0 & 9279 & 0.0 & 15333.0 & 15333 & 0.0 \\
\hline
\end{tabular}

${ }^{\mathrm{z}}$ Represent excess availability (for differences in excess of $+/-70$ trees)

${ }^{y}$ Represent deficient availability (for differences in excess of $+/-70$ trees).

\section{CONCLUSION}

Results from this study highlight the need for establishing stronger lines of communication between nursery stock suppliers and urban foresters. Requests for nursery stock by responding urban foresters were found to represent only $3 \%-5 \%$ of Ohio nursery production. Thus nurseries have many additional customers. Urban foresters must communicate with nursery suppliers and let them know what they will need and when they are satisfied with their services. The segmentation of the nursery industry into various components such as seedling production, whip production, wholesale producers, and brokers over the past decades has likely resulted in reduced prices for consumers. One of the casualties of segmenting the supply chain has been the limited communication between segments, especially those growers early in the production cycle and end users such as urban foresters.

Another difficulty arises when an urban forester requests an oak (309 shortfall for 2010), for example, but has to accept a maple substitute since oaks are not available from the success- ful bidder. The nursery then logs the substituted maple as a sale, using sales data in determining what to plant the following year. In this way, information regarding the original request might be lost and market disequilibrium can result. Some nurseries see this as a means of managing inventory. Still others are willing to work with customers to bring plants to market not currently in inventory; for several species, the quantities being demanded and supplied were somewhat balanced (Appendix 2).

Maples, crabapples, many hawthorns, and pears are generally present in nurseries in excess of what urban foresters demand. Some of these excesses represent plants being grown for other purposes such as pines for screening or Japanese maples for decorative purposes. Conversely, many legumes, oaks, elms, lilacs, and lindens are deficient in availability; such species likely represent plants purchased by Ohio community foresters from out-of-state sources. Urban foresters can increase taxonomic diversity by informing their preferred nursery suppliers of the plants they expect to purchase, ordering those 
plants, and not accepting substitutes when the low bidder says the plants are not available. This will increase the taxonomic diversity in their communities and in the nursery industry as well.

\section{LITERATURE CITED}

Anonymous. 2008. Ohio Nursery Stock Survey, 38th Edition. Ohio Nursery and Landscape Association. <http://www.onla.org/newsite/ survey/php/survey_results2.php3> Accessed March 2008.

Fater, R. 2008. ALB raises its ugly head and horns in Massachusetts. Tree Care Industry 19(10):32-37.

McBride, J.R. 2008. A Method for Characterizing Urban Forest Composition and Structure for Landscape Architects and Urban Planners. Arboriculture \& Urban Forestry 34(6):359-365.

Low, J.D. 2008. Personal communication. City Forester, Columbus Recreation Parks Department, City of Columbus, Ohio.

Santamour, F.S., Jr. 1990. Trees for urban planting: Diversity, uniformity and common sense. Proceedings of the 7th Conference of the Metropolitan Tree Improvement Alliance (METRIA) 7:57-65.

Sydnor, T.D. 1996. Your customer's needs for the year 2000. The Buckeye Educational Update, August 1996. Ohio Nursery and Landscape Assn., Columbus, OH. 7 pp.

Sydnor, T.D., D. Todd, J. Chatfield, and D. Balser. 1999. Street Tree Evaluation Project. Ohio State University Extension Bulletin \#877. Columbus, OH. 104 pp.

Sydnor, T.D., N.E. D'Amato, and D.K. Struve. 2000. Your customer's needs for the year 2005. The Buckeye Educational Update, August 2000. Ohio Nursery and Landscape Association, Columbus OH. 8 pp.

Sydnor, T.D., M. Bumgardner, and A. Todd. 2007. The potential impacts of emerald ash borer (Agrilus planipennis) on Ohio, U.S., communities. Arboriculture \& Urban Forestry 33(1):48-54.

Sydnor, T.D. 2008. More Than 15,000 Tree Requests For Spring $2010-$ Are You Interested? The Buckeye Educational Update, August 2008. Ohio Nursery and Landscape Association. Columbus, OH. 8 pp.

Sydnor T.D., and S. Subburayalu. 2008a. An Analysis of Street Tree Benefits for Toledo, Ohio. <http://snr.osu.edu/urbanforestry/evaluation. html> Accessed September 18, 2008.

Sydnor, T.D., and S. Subburayalu. 2008b. A comparison of the environmental benefits of street trees between an established and a younger community in Ohio. Why Trees Matter: A Research Summary. Res. Cir., Ohio Agricultural Research and Development Center (in press).

\author{
T. Davis Sydnor (corresponding author) \\ Professor of Urban Forestry \\ School of Environment and Natural Resources \\ The Ohio State University \\ 2021 Coffey Road \\ Columbus, OH 43210-1085, U.S. \\ sydnor.1@osu.edu \\ Sakthi Subburayalu \\ Post Doctoral Researcher \\ School of Environment and Natural Resources \\ The Ohio State University
}

Matthew Bumgardner

Research Forest Products Technologist

USDA Forest Service

359 Main Road, Delaware, OH 43015, U.S.
Résumé. Il y a une disparité continue entre ce que les forestiers urbains affirment avoir besoin pour la plantation dans les villes et les stocks disponibles dans les pépinières. Pour étudier cette question, une enquête a été faite en février 2008 auprès de 22 des forestiers urbains de l'Ohio afin de comparer le contraste entre leurs besoins en plantation et la disponibilité des stocks en pépinière. Les forestiers ont indiqué avoir planté plus de 9000 arbres en 2005 et comptaient en planter plus de 15000 arbres dans leurs villes respectives en 2010. Au même moment, il a été fait mention que près de 278000 arbres de $5 \mathrm{~cm}$ de calibre étaient disponibles pour la vente auprès des pépinières participantes en 2008. Ces résultats suggèrent que les érables, les pommetiers, plusieurs aubépines et les poiriers présents dans les pépinières étaient en excès par rapport aux quantités désirées par les forestiers urbains. À l'inverse, plusieurs légumineuses, chênes, ormes, lilas et tilleuls se trouvaient en quantités inférieures aux besoins. Plusieurs autres espèces étaient plus ou moins en quantités équivalentes entre les besoins des forestiers urbains et celles disponibles en pépinières. L'Ohio a été confronté aux impacts de l'agrile du frêne sur les espèces du genre Fraxinus. Une diversité taxonomique accrue pourrait être une méthode à faible coût pour s'assurer d'éviter une possible introduction d'un nouveau parasite exotique qui pourrait possiblement attaquer un autre genre (ex.: Acer), ce qui requiert une disponibilité accrue de certaines espèces actuellement manquantes au sein de la chaîne de production en pépinière.

Zusammenfassung. Es gibt eine kontinuierliche Differenz zwischen den Anforderungen, die von den verantwortlichen Forstplanern an die Bäume gestellt werden und der in der Baumschule erhältlichen Qualität. Um dieses näher zu untersuchen, wurden im Februar 2008 zweiundzwanzig Stadtförster in Ohio im Hinblick auf ihre Planungsanforderungen und des tatsächlichen Angebots in den Baumschulen befragt. Die Stadtförster berichteten, daß sie in 2005 mehr als 5.000 Bäume gepflanzt hätten und daß sie für 2010 mehr als 15.000 in ihren Bezirken pflanzen wollen. Zur gleichen Zeit waren in den Baumschulen, die sich an der Umfrage bezüglich ihres Angebots in 2008 beteiligt hatten, nahezu 278.000 Bäume zum Kauf erhältlich. Die Ergebnisse zeigten, daß Äpfel, Zieräpfel, viele Weißdorne und Birnen in der von den Stadtförstern gewünschten Anzahl erhältlich waren. Auf der anderen Seite waren viele Hülsenfrüchte, Eichen, Ulmen, Flieder und Linden nicht ausreichend vorhanden. Bei einigen anderen Arten gab es ein ausgeglichenes verhältnis zwischen Angebot und Nachfrage. Ohio muss sehr mit den Schäden des Eschenbohrers kämpfen. Zunehmende taxonomische Diversität könnte eine preiswerte Alternative sein zu der möglichen Einführung von weiteren Schädlingen, die eine andere Baumart befallen (zum Beispiel Ahorn) und das erfordert ein wachsendes Angebot von einigen Arten, die derzeit in den Baumschulen nicht oder nicht ausreichend erhältlich sind.

Resumen. Ha habido una continua disparidad entre las especies que los dasónomos urbanos requieren para las plantaciones y la disponibilidad en los viveros. Para investigar esto, veintidós de los dasónomos de Ohio fueron encuestados en Febrero de 2008 para contrastar sus necesidades de plantación con la disponibilidad en los viveros. Los dasónomos urbanos reportaron una plantación de más que 9,000 árboles en 2005 y esperan plantar más de 15,000 en sus respectivas comunidades en 2010. Al mismo tiempo, aproximadamente 278,000 árboles [ $5 \mathrm{~cm}$ (2 in)] fueron reportados disponibles para la venta en los viveros participantes en la encuesta de 2008 en Ohio. Estos resultados sugieren que los maples, manzanos, muchos piracantos y perales generalmente estuvieron en exceso en los viveros, en comparación a las cantidades deseadas por los dasónomos. Contrariamente, muchas leguminosas, encinos, olmos, lilas y tilos estaban ausentes. Varias otras especies estuvieron balanceadas en términos de las necesidades y la producción de los viveros. Ohio, U. S. ha estado tratando con los impactos del barrenador esmeralda en las especies de Fraxinus. El incremento en la diversidad taxonómica puede ser, a un costo relativamente bajo, un medio de asegurarse contra la posible introducción de esta y otras plagas exóticas que pudieran atacar otros géneros (tales como Acer). Se requiere incrementar la disponibilidad de algunas especies faltantes en cuanto a disponibilidad en los viveros en la cadena de abastecimiento. 
APPENDIX 1. AN ABBREVIATED SURVEY INSTRUMENT SHOWING THE FIRST FIVE ENTRIES OF THE ORIGINAL LIST THAT CONTAINED MORE THAN 200 SPECIES. THE HEADER AND THE FIRST TWO COLUMNS WERE FILLED OUT BY RESPONDENTS. THE REMAINING FOUR COLUMNS WERE USED FOR CODING AND TO IDENTIFY PLANTS IN THE SURVEY.

PLANTING SURVEY FORM

Insert the approximate number of trees planted in 2005 for each species that you planted in the first column. Insert the estimated number for each species you wish to plant in 2010 assuming no problems with availability.

Community Phone No. Expected Size

\begin{tabular}{|c|c|c|c|c|c|c|c|}
\hline \multirow{2}{*}{$\begin{array}{l}\text { PLANTED } \\
\text { IN 2005 } \\
\end{array}$} & \multirow{2}{*}{$\begin{array}{c}\text { EXPECTED } \\
\text { FOR } 2010\end{array}$} & \multirow{2}{*}{$\begin{array}{c}\text { SCIENTIFIC } \\
\text { NAME }\end{array}$} & \multirow{2}{*}{ COMMON NAME } & \multirow{2}{*}{ FAMILY } & \multicolumn{3}{|c|}{ CODES } \\
\hline & & & & & FmC & GnC & SpC \\
\hline & & Acer buergeranum & Trident Maple & Aceraceae & 15 & 18 & 15 \\
\hline & & Acer campestre & Hedge Maple and cultivars & Aceraceae & 15 & 18 & 20 \\
\hline & & Acer circinatum & Vine Maple & Aceraceae & 15 & 18 & 22 \\
\hline & & Acer ginnala & Amur Maple and cultivars & Aceraceae & 15 & 18 & 30 \\
\hline & & Acer griseum & Paperbark Maple & Aceraceae & 15 & 18 & 35 \\
\hline
\end{tabular}




\section{APPENDIX 2. LIST OF TREES EVALUATED WHERE URBAN FORESTERS' REQUESTS AND NURSERY PRODUCTION APPROACHED BALANCE (DIFFERENCES WITHIN +/- 70 TREES).}

Acer circinatum

Acer griseum

Acer negundo

Acer nigrum

Acer pensylvanicum

Acer pseudoplatanus

Acer saccharinum

Acer tataricum

Acer truncatum

Aesculus glabra

Aesculus Hippocastanum

Aesculus octandra

Aesculus Pavia

Ailanthus altissima

Alnus glutinosa

Amelanchier $\times$ grandiflora

Asimina triloba

Betula alleghaniensis

Betula lenta

Betula nigra

Betula papyrifera

Betula pendula

Betula populifolia

Betula utilis

Carpinus Caroliniana

Carya cordiformis

Carya glabra

Carya illinoinensis

Carya ovata

Catalpa bignonioides

Catalpa speciosa

Celtis laevigata

Celtis occidentalis

Celtis reticulata

Cercidiphyllum japonicum

Chionanthus retusus

Chionanthus virginicus

Cornus alternifolia

Cornus Drummondii

Cornus florida

Cornus mas

Cornus officinalis

Crataegus crus-galli

Crataegus Phaenopyrum

Crataegus punctata

Crataegus $\times$ Lavalle

Diospyros virginiana

Fagus grandifolia

Fraxinus excelsior

Fraxinus pennsylvanica

Gleditsia triacanthos

Halesia carolina

Halesia monticola

Hibiscus syriacus

Ilex opaca

Juglans cinerea

Juglans nigra
Juniperus chinensis

Koelreuteria paniculata

Liquidambar styraciflua

Liriodendron Tulipifera

Maackia amurense

Magnolia acuminata

Magnolia grandiflora

Magnolia Kobus

Magnolia stellata

Magnolia virginiana

Magnolia $\times$ Loebneri

Magnolia $\times$ Soulangiana

Malus baccata

Malus floribunda

Malus hupehensis

Malus ioensis

Malus sieboldii zumi

Malus tschonoskii

Metasequoia glyptostroboides

Morus species

Nyssa sylvatica

Ostrya virginiana

Oxydendrum arboreum

Pinus Bungeana

Pinus flexilis

Pinus nigra

Pinus ponderosa

Pinus rigida

Pinus sylvestris

Pinus virginiana

Platanus occidentalis

Populus deltoides

Populus spp

Prunus Padus

Prunus Sargentii

Prunus serotina

Prunus serrulata

Prunus virginiana

Prunus yedoensis

Pseudotsuga Menziesii

Ptelea trifoliata

Pyrus betulifolia

Pyrus Fauriei

Quercus alba

Quercus coccinea

Quercus lyrata

Quercus marilandica

Quercus Muehlenbergii

Quercus nigra

Quercus phellos

Quercus prinus

Quercus robur

Quercus stellata

Quercus velutina

Rhus typhina

Robinia Pseudoacacia

Robinia $\times$ ambigua
Salix babylonica

Salix nigra

Sassafras albidum

Sophora japonica

Sorbus alnifolia

Stewartia Pseudocamellia

Styrax japonicus

Taxodium distichum

Tilia cordata

Ulmus carpinifolia

Ulmus japonica

Viburnum lentago

Viburnum prunifolium

Viburnum rufidulum 